\title{
Persistent perioperative tachycardia and hypertension diagnosed as thyroid storm induced by a hydatidiform mole -a case report-
}

\author{
Wonjung Hwang, Daehwan Im, and Eunsung Kim
}

Department of Anesthesiology and Pain Medicine, Seoul St. Mary's Hospital, The Catholic University of Korea College of Medicine, Seoul, Korea

Thyroid storm is a critical complication of molar pregnancy. However, early diagnosis of it is difficult because it is a rare complication and usually presents nonspecific findings. In this case report, we present a woman with molar pregnancy who had persistent tachycardia and hypertension. She was diagnosed initially with preeclampsia and sepsis as complications of molar pregnancy. During dilation and curettage under general anesthesia with sevoflurane and remifentanil, tachycardia and hypertension remained even with continuous infusion of labetalol. The patient was subsequently diagnosed with thyroid storm associated with molar pregnancy. She was restored to a clinically euthyroid state 1 day after the operation, and her thyroid function test and $\beta$-hCG values were normal 3 months later. The anesthesiologists should bear in mind the possibility of thyroid storm in patients with molar pregnancies who show persistent tachycardia and hypertension. (Korean J Anesthesiol 2014; 67: 205-208)

Key Words: Hydatidiform mole, Thyroid crisis.

Perioperative tachycardia and hypertension are common medical problems but sometimes uncontrollable due to serious conditions such as thyroid storm.

Molar pregnancy can lead to thyroid storm, which is an endocrine emergency [1]. However, early diagnosis of thyroid storm in patients with molar pregnancy can be difficult because it is a rare complication and usually presents nonspecific findings like tachycardia and hypertension, which are symptoms also found in other complications of molar pregnancy such as hemorrhage or sepsis [2].
In this case report, we describe a patient with persistent perioperative tachycardia and hypertension who was diagnosed belatedly with thyroid storm induced by molar pregnancy.

\section{Case Report}

A 27-year-old woman (height $156 \mathrm{~cm}$, weight $44 \mathrm{~kg}$ ) who was 16 weeks pregnant was scheduled for emergency dilation and curettage (D\&C). She was diagnosed with missed abortion with a hydatidiform mole in a local clinic and transferred to our

Received: February 28, 2013. Revised: 1st, May 27, 2013; 2nd, July 10, 2013. Accepted: August 2, 2013.

Corresponding author: Eunsung Kim, M.D., Ph.D., Department of Anesthesiology and Pain Medicine, Seoul St. Mary's Hospital, The Catholic University of Korea College of Medicine, 222 Banpodaero, Seocho-gu, Seoul 137-701, Korea. Tel: 82-2-2258-2236, Fax: 82-2-537-1951, E-mail: euns1503@catholic.ac.kr

() This is an open-access article distributed under the terms of the Creative Commons Attribution Non-Commercial License (http:// creativecommons.org/licenses/by-nc/3.0/), which permits unrestricted non-commercial use, distribution, and reproduction in any medium, provided the original work is properly cited. 
hospital for further treatment. She had no medical or surgical history, and her vital signs upon admission were 160/95 $\mathrm{mmHg}$ $88 / \mathrm{min}-20 / \mathrm{min}-36.5^{\circ} \mathrm{C}$. Her chest X-ray, electrocardiogram, and laboratory tests completed at the local clinic were normal, with the exception of the beta human chorionic gonadotropin ( $\beta$-hCG) level of 1,046,900 mIU/ml (normal: 0.5-2.9 mIU/ml). After vaginal insertion of misoprostol (prostaglandin E1) for abortion, she developed chilling sensations and vital signs were $156 / 106 \mathrm{mmHg}-125 / \mathrm{min}-20 / \mathrm{min}-38.1^{\circ} \mathrm{C}$. The obstetricians removed the misoprostol due to suspected side effects, but the chilling sensations continued. She showed nausea and agitation with a blood pressure (BP) of $183 / 107 \mathrm{mmHg}$ and heart rate (HR) of $158 / \mathrm{min}$. The obstetricians suspected preeclampsia and magnesium sulfate and hydralazine were administered repeatedly, but they were not effective for controlling the BP and HR. The obstetricians considered septic complications from the hydatidiform mole and we decided to perform an emergency D\&C under general anesthesia. This situation was considered critical, and we conducted the anesthesia before the results of laboratory test done in our clinic were known.

After arrival in the operating room, routine monitors were applied and vital signs were 169/85 mmHg- $180 / \mathrm{min}-40 / \mathrm{min}$ $38.1^{\circ} \mathrm{C}$. Anesthesia was induced with pentotal sodium $(200 \mathrm{mg})$ and rocuronium $(20 \mathrm{mg})$. After intubation, esmolol $(20 \mathrm{mg})$ and nicardipine $(0.5 \mathrm{mg})$ were given to attenuate the hemodynamic response. Anesthesia was maintained with 1.5 vol\% sevoflurane in medical air $\left(\mathrm{FiO}_{2} 0.5\right)$ and remifentanil in $4.0-6.0 \mathrm{ng} / \mathrm{ml}$ by a target-controlled infusion (TCI, Orchestra ${ }^{\circledR}$ Base Primea, Fresenius Vial, Grenoble, France). Esmolol (10-30 mg) and nicardipine (0.5-1.0 mg) were administered intermittently, but hypertension and tachycardia persisted. Labetalol was infused continuously and her BP and HR decreased to 130-140/60-80 $\mathrm{mmHg}$ and 105-120, respectively. At the end of the 20-min operation, the recovery from the muscle relaxant was incomplete and she was sent to the recovery room in an intubated state. The estimated blood loss was $100 \mathrm{ml}$, and $500 \mathrm{ml}$ crystalloid was infused.

After $20 \mathrm{~min}$ in the recovery room, the neuromuscular block was measured by the train-of-four ratio and reversed with 0.2 $\mathrm{mg}$ glycopyrrolate and $10 \mathrm{mg}$ pyridostigmine. After extubation, persistent hypertension of 130-160/90-100 mmHg, tachycardia of around $130-140 / \mathrm{min}$, and hyperthermia of $37.9^{\circ} \mathrm{C}$ were noted. No proteinuria or leukocytosis was found on preoperative laboratory tests done in our clinic, and preeclampsia and sepsis were ruled out. Physical examination and laboratory tests were repeated to find the cause of continuous tachycardia and hypertension. We found a small lump on her neck and suspected a thyroid storm. A thyroid function test (TFT) was done and she was transferred immediately to endocrinology. Hydrocortisone $(200 \mathrm{mg}$ ) was administered empirically and labetalol was infused continuously to control her BP and HR. An ice bag and intravenous cold fluid were applied to reduce her fever.

Postoperative TFT showed elevated triiodothyronine (T3)/ thyroxine (T4) levels and a decreased thyroid-stimulating hormone (TSH) level (Table 1). An endocrinologist diagnosed her with secondary thyrotoxicosis due to molar pregnancy. One day after her operation, she was in a clinically euthyroid state and no further treatments were needed. The patient was discharged on the fourth day after the operation without complications. The TFT and $\beta$-hCG values returned to normal 3 months later (Table 1).

\section{Discussion}

Thyroid storm is an endocrine emergency; however, no diagnostic criteria are defined because it usually represents several nonspecific findings such as tachycardia, hypertension, hyperthermia, delirium, and irritability. These conditions can also be found in many other diseases during the perioperative period, making immediate diagnosis difficult. The differential diagnosis of thyroid storm during the perioperative period includes anaphylactic reaction, malignant hyperthermia, sepsis, pheochromocytoma, or untreated hypertension [3]. In this case, no known triggering agents of an anaphylactic reaction or malignant hyperthermia were used, and no past history or family history of pheochromocytoma or hypertension were present. We considered preeclampsia or sepsis preferentially because they are more common complications than thyroid storm in hydatidiform mole, and we had no time to preoperatively confirm the laboratory tests. The use of misoprostol may have delayed an early diagnosis of thyroid storm.

When thyroid storm is suspected, treatment should not be delayed until TFT results were confirmed. These patients need

Table 1. Thyroid Function Test Values and Levels of $\beta$-hCG on Perioperative Period

\begin{tabular}{lccccc}
\hline & Surgical day & 2 weeks after surgery & 2 months after surgery & 3 months after surgery & Reference ranges \\
\hline FT4 $(\mu \mathrm{g} / \mathrm{dl})$ & 2.7 & 0.79 & 1.02 & 1 & $0.93-1.7$ \\
T3 $(\mathrm{ng} / \mathrm{dl})$ & 1.78 & 0.97 & 1.07 & 0.77 & $0.6-1.81$ \\
TSH $(\mu \mathrm{IU} / \mathrm{ml})$ & 0.008 & 0.011 & 0.507 & 0.992 & $0.55-4.78$ \\
$\beta-\mathrm{hCG}(\mathrm{mIU} / \mathrm{ml})$ & 1046900 & 3360 & 23.72 & 1.87 & $0.5-2.9$ \\
\hline
\end{tabular}

FT4: free thyroxin, T3: triiodothyronine, TSH: thyroid-stimulating hormone. 
intensive monitoring, antithyroid drugs, a supplement for systemic decompensation from a hypermetabolic state, and the elimination of precipitating events [4,5]. Burch and Wartofsky [6] developed a scoring system for early detection of thyroid storm based on the degree of dysfunction in the various organ systems (Appendix 1). According to this scoring system, our patient received a score of 55 due to the presence of fever, agitation, nausea, and tachycardia, which is highly suggestive of thyroid storm requiring emergent treatments. Our patient was restored to a clinically euthyroid state after surgery and the change in TFT was not significant. So she received only conservative management including aggressive fluid and electrolyte replacement, antipyretics, corticosteroids, and $\beta$-blockers.

Clinical hyperthyroidism is common in normal pregnancy, with an incidence of about 1 in 100 pregnant women [7]. This condition is associated with a structural similarity between $\beta$-hCG and TSH. Hyperthyroidism is more common in molar pregnancy than in normal pregnancy, occurring in approximately $5 \%$. Three reasons for this high prevalence are 1) the concentration of $\beta$-hCG is much higher in molar pregnancy than in normal pregnancy; 2) less sialylated $\beta$-hCG in molar pregnancy has a more potent thyrotropic effect compared to that in normal pregnancy: $1 \mathrm{U} \beta$-hCG in normal pregnancy is equivalent to $0.013 \mu \mathrm{U} \mathrm{TSH}$, whereas $1 \mathrm{U}$ molar $\beta$-hCG is equivalent to 3.72-46.8 $\mu \mathrm{U}$ TSH [8-10]; and 3) $\beta$-hCG in molar pregnancy has synergistic effects on TSH.

The treatment for complicated molar pregnancy is $\mathrm{D} \& \mathrm{C}$, and there were several reports of anesthetic management for molar pregnancy with thyroid storm. Cekic et al. [11] suggested regional anesthesia for $\mathrm{D} \& \mathrm{C}$ treatment of molar pregnancy with thyroid storm because of the tocolytic effect of inhaled anesthetics and hemodynamic response to laryngoscope and intubation. Erturk et al. [12] used propofol and remifentanil as anesthetics for D\&C of molar pregnancy with thyrotoxicosis. The authors explained that propofol and remifentanil have no tocolytic effect, cause a dose-dependent decrease in HR and BP and reduce the intraoperative blood loss by hypotensive anesthesia. Although we initially planned regional anesthesia, our patient was extremely agitated and emergency surgery was required; therefore, regional anesthesia was considered inappropriate. We used remifentanil to control the HR and BP, but propofol has a potent vasodilatory effect and may induce rebound tachycardia; therefore, we used low-dose inhaled anesthetics. In this case, the patient had a partial hydatidiform mole and the duration of pregnancy was relatively short. Thus, tocolysis by inhaled anesthetics was mild with little intraoperative blood loss.

In conclusion, molar pregnancy-induced thyroid storm is a rare but serious complication that can be fatal. Anesthesiologists should bear in mind the possibility of thyroid storm in women with molar pregnancy during the perioperative period and should be considered in cases with persistent tachycardia and hypertension. In addition, low-dose inhaled anesthetics with remifentanil may be useful for anesthetic management in molar pregnancy-induced thyroid storm.

\section{References}

1. Berkowitz RS, Goldstein DP, DuBeshter B, Bernstein MR. Management of complete molar pregnancy. J Reprod Med 1987; 32: 634-9.

2. Al-Mulhim AA. Hydatidiform mole: a study of 90 cases. J Family Community Med 2000; 7: 57-61.

3. Hirvonen EA, Niskanen LK, Niskanen MM. Thyroid storm prior to induction of anaesthesia. Anaesthesia 2004; 59: 1020-2.

4. Nayak B, Burman K. Thyrotoxicosis and thyroid storm. Endocrinol Metab Clin North Am 2006; 35: 663-86.

5. Wilkinson JN. Thyroid storm in a polytrauma patient. Anaesthesia 2008; 63: 1001-5.

6. Burch HB, Wartofsky L. Life-threatening thyrotoxicosis. Thyroid storm. Endocrinol Metab Clin North Am 1993; 22: 263-77.

7. Glinoer D. The regulation of thyroid function in pregnancy: pathways of endocrine adaptation from physiology to pathology. Endocr Rev 1997; 18: 404-33.

8. Tomer Y, Huber GK, Davies TF. Human chorionic gonadotropin (hCG) interacts directly with recombinant human TSH receptors. J Clin Endocrinol Metab 1992; 74: 1477-9.

9. Yoshimura M, Pekary AE, Pang XP, Berg L, Goodwin TM, Hershman JM. Thyrotropic activity of basic isoelectric forms of human chorionic gonadotropin extracted from hydatidiform mole tissues. J Clin Endocrinol Metab 1994; 78: 862-6.

10. Yamazaki K, Sato K, Shizume K, Kanaji Y, Ito Y, Obara T, et al. Potent thyrotropic activity of human chorionic gonadotropin variants in terms of 125I incorporation and de novo synthesized thyroid hormone release in human thyroid follicles. J Clin Endocrinol Metab 1995; 80: 473-9.

11. Cekic B, Geze S, Ulusoy H, Coskun I, Erturk E. Postoperative repeated respiratory insufficiency and thyrotoxicosis in molar pregnancy. Ir J Med Sci 2012; 181: 281-3.

12. Erturk E, Bostan H, Geze S, Saracoglu S, Erciyes N, Eroglu A. Total intravenous anesthesia for evacuation of a hydatidiform mole and termination of pregnancy in a patient with thyrotoxicosis. Int J Obstet Anesth 2007; 16: 363-6. 
Appendix 1. Diagnostic Scoring System for Thyroid Storm

\begin{tabular}{|c|c|}
\hline Diagnostic parameter & Scoring points \\
\hline \multicolumn{2}{|l|}{$\begin{array}{l}\text { Thermoregulatory dysfunction } \\
\text { temperature }\end{array}$} \\
\hline $37.2-37.72^{\circ} \mathrm{C}\left(99-99.9^{\circ} \mathrm{F}\right)$ & 5 \\
\hline $37.78-38.28^{\circ} \mathrm{C}\left(100-100.9^{\circ} \mathrm{F}\right)$ & 10 \\
\hline $38.33-38.83^{\circ} \mathrm{C}\left(101-101.9^{\circ} \mathrm{F}\right)$ & 15 \\
\hline $38.89-39.39^{\circ} \mathrm{C}\left(102-102.9^{\circ} \mathrm{F}\right)$ & 20 \\
\hline $39.44-39.94^{\circ} \mathrm{C}\left(103-103.9^{\circ} \mathrm{F}\right)$ & 25 \\
\hline$\geq 40^{\circ} \mathrm{C}\left(104.0^{\circ} \mathrm{F}\right)$ & 30 \\
\hline \multicolumn{2}{|l|}{ Central nervous systemic effects } \\
\hline Absent & 0 \\
\hline $\begin{array}{l}\text { Mild } \\
\quad \text { Agitation }\end{array}$ & 10 \\
\hline $\begin{array}{l}\text { Moderate } \\
\text { Delirium } \\
\text { Psychosis } \\
\text { Extreme lethargy }\end{array}$ & 20 \\
\hline $\begin{array}{l}\text { Severe } \\
\text { Seizure } \\
\text { Coma }\end{array}$ & 30 \\
\hline \multicolumn{2}{|l|}{ Gastrointestinal-hepatic dysfunction } \\
\hline Absent & 0 \\
\hline $\begin{array}{l}\text { Moderate } \\
\text { Diarrhea } \\
\text { Nausea/vomiting } \\
\text { Abdominal pain }\end{array}$ & 10 \\
\hline Severe & 30 \\
\hline Unexplained jaundice & \\
\hline \multicolumn{2}{|l|}{$\begin{array}{l}\text { Cardiovascular dysfunction } \\
\text { tachycardia (beats/min) }\end{array}$} \\
\hline $90-109$ & 5 \\
\hline $110-119$ & 10 \\
\hline $120-129$ & 15 \\
\hline $130-139$ & 20 \\
\hline$\geq 140$ & 25 \\
\hline \multicolumn{2}{|l|}{ Congestive heart failure } \\
\hline Absent & 0 \\
\hline $\begin{array}{l}\text { Mild } \\
\quad \text { Pedal edema }\end{array}$ & 5 \\
\hline $\begin{array}{l}\text { Moderate } \\
\quad \text { Bibasilar rales }\end{array}$ & 10 \\
\hline $\begin{array}{l}\text { Severe } \\
\quad \text { Pulmonary edema }\end{array}$ & 15 \\
\hline \multicolumn{2}{|l|}{ Atrial fibrillation } \\
\hline Absent & 0 \\
\hline Present & 10 \\
\hline \multicolumn{2}{|l|}{ Precipitant history } \\
\hline Negative & 0 \\
\hline Positive & 10 \\
\hline
\end{tabular}

Scoring: $<25=$ unlikely to be thyroid storm; $25-44=$ suggestive of impending storm; $\geq 45$ = highly suggestive of thyroid storm. Points are assigned to the highest weighted description applicable in each category and scores totaled. 